on the fossils he had collected in Chitral. However, he was soon invited to act as a minerals adviser to the High Commissioner for India, where his wide experience and exceptional memory were invaluable.

At the outbreak of war in 1939, Tipper went for a short time to the Department of Economic Warfare and thence to the Ministry of Supply as 'the acknowledged expert of experts' on mica. In 1941 he went as a representative of Great Britain and the Government of India to the United States to help in the organisation of supplies of mica on both sides of the Atlantic, and was attached to the British Raw Materials Mission in Washington. Altogether, he made the double crossing of the Atlantic four times during the War; he flew to India via New Zealand and Australia and also to Brazil. This last trip was a particularly arduous one. On his return to Great Britain, he continued at the Mica Control and eventually became director, until he was compelled to resign on account of ill-health in October 1946. His services were so much valued by the Board of Trade that he was retained as a consultant until his death on April 23, 1947.

Tipper combined the rare qualities of the trained geologist with an intimate acquaintance of the mica trade in all its aspects; but he could not have carried out his war-time work with such success if his complete honesty had not made him trusted and liked by everyone. His devotion to his work compelled him to embark on a series of journeys which many a younger man would have found exhausting, and kept him at work when he was already in bad health. One of his colleagues writes: "I don't suppose that the State ever received more selfless service from a man of great ability than England got from him".

\section{Dr. Leopold von Portheim}

THE botanist, Dr. Leopold von Portheim, died in London on May 21. He had been seriously ill for some time. Portheim was born in Prague on Feb. ruary 7,1869 , and studied botany there and at Vienna, where he was a pupil of Dr. Julius von Wiesner. He thus lived to be one of the last surviving botanists who were trained by this great master.

One of the most notable achievements in which Portheim took a leading part was the foundation of the Biologische Versuchsanstalt in Vienna in 1901. In this he was associated with Prof. Hans Przibram and Prof. Wilhelm Figdor. The Institute founded by these biologists later became an important centre for research into the physiology of plants and animals. After the First World War the laboratory was presented to the Academy of Sciences in Vienna, Portheim being director of the department of botany. The Institute was destroyed during the Second World War.

When Austria fell under Nazi domination, Portheim's botanical career in that 'country came to an untimely end, for he was forced to leave the institute which he himself had helped to found, and he fled from the country. Arriving in Great Britain in December 1938 with a note of introduction from the famous Swiss botanist, Carl Schröter of Zurich, he was given hospitality at the Jodrell Laboratory at the Royal Botanic Gardens, Kew, by the late Sir Arthur W. Hill, who was then director of the Gardens. $\mathrm{He}$ continued to work at Kew until afflicted with the illness from which he died.
Although his work is not very familiar to British workers, Portheim published papers dealing with plant physiology and related subjects. During the First World War his investigations were concerned especially with the production of fats by some of the lower fungi. $\mathrm{He}$ also studied the influence of light on the growth of plants, and later became interested in the action of plant growth substances. The researches on heteroauxin which he started in Vienna were continued at Kew, where he also performed the remarkable achievement of keeping various members of the xerophytic Cactaceæ alive, and caused them to flower in jars of tap water during a period of about five years. He also did some experimental work on antibiotic substances. During his time at Kew he was severely handicapped by poor eyesight, which made it impossible for him to use a microscope. Nevertheless, the extreme care and patience with which he followed his experiments were most praiseworthy, while his attention to detail was such that not even the most trivial facts escaped his notice.

Portheim, who travelled extensively in Europe and also visited the United States, was a man of great personal charm and kindliness, while he was endowed with a keen sense of humour. His extreme modesty and retiring disposition undoubtedly led many to under-estimate his wide knowledge of the physiology of plants. Those who were privileged to know him more intimately found him to have a wide and cultured outlook and to be a firm friend. He will for long be remembered by all who worked at the Jodrell Laboratory while he was there. He leaves a widow and married daughter. C. R. METCALFE

\section{Prof. J. Velíšek}

By the death of Dr. Joseph Velíšek, professor of physical chemistry at Brno Technical College, on February 2, Czechoslovakia is deprived of another comparatively young and energetic teacher and investigator. Velíšek was only fifty years of age and had not long succeeded Prof. Baborovský, whose assistant he had been for many years. In 1922-23 Velísek, under Jorissen at Leyden in Holland, investigated the influence of the vapours of noninflammable liquids on the explosion limits of methane-air mixtures. His other scientific work included a special study of the hydration of lithium ions, the electro-osmosis of alkali chlorides and other salts through porcelain diaphragms, the use of calcium for electrodes and an examination of the 'turbulent' or 'hydraulic' flow of liquids. Prof. Velíšek was a keen amateur cinematographer. J. G. F. DRUCE

We regret to announce the following deaths :

Mr. B. Hilton Barrett, lecturer in geology in the University of Glasgow for nearly thirty years, on June 9.

Dr. D. E. Lea, reader in radiobiology in the University of Cambridge, on June 16, aged thirtyseven.

Prof. Philip W. Schutz, professor of chemical engineering in the University of California, known for his work in chemical engineering thermodynamics and dielectric heating, on March 7, aged thirty-eight.

Prof. A. F. Bernard Shaw, professor of pathology in the University of Durham, and during 1933-38 professor of pathology in the Egyptian University, Cairo, on June 3, aged fifty-eight. 